\title{
ANALISIS EFISIENSI BANK UMUM SYARIAH DEVISA DI INDONESIA DENGAN METODE DATA ENVELOPMENT ANALYSIS STUDI PADA BANK MUAMALAT INDONESIA DAN BANK SYARIAH MANDIRI
}

Helmi Haris dan Nuning Sri Hastuti

Institut Agama Islam Negeri Surakarta

helmi.solo@gmail.com

\begin{abstract}
Abstrak
Kinerja merupakan salah satu indikator efisiensi dalam perusahaan termasuk bank syariah. Pengukuran kinerja yang lazim dilakukan oleh bank syariah adalah menggunakan rasio keuangan. Namun pengukuran kinerja dengan menggunakan rasio keuangan tidak dapat menunjukkan kondisi bank syariah jujur. Metode Data Envelopment Analysis (DEA) dapat mengatasi keterbatasan sarana pengukuran kinerja yang mampu menangani banyak input dan output. Metode DEA adalah pemrograman linier yang bertujuan untuk memaksimalkan input dan output. Penelitian ini bertujuan untuk mengetahui dan menganalisis kinerja keuangan bank umum syariah melalui metode DEA dalam periode 2008-2011. Sampel penelitian ini dari dua bank umum syariah, Bank Muamalat Indonesia dan Bank Syariah Mandiri. Penelitian ini menggunakan variabel input yang terdiri dari deposito, aset, dan biaya personil serta menggunakan variabel output yang terdiri dari jumlah pembiayaan dan pendapatan operasional. Adapun Hasil penelitian menunjukkan bahwa bank umum syariah devisa yang secara kontinyu memiliki efisiensi $100 \%$ adalah Bank Muamalat Indonesia selama periode observasi. Sedangkan Bank Syariah Mandiri memiliki efisiensi $100 \%$ pada Maret 2008, September 2008, Desember 2008 , Juni 2009 , September 2009, Desember 2009, September 2010, Desember 2010, Maret 2011, Juni 2011, September 2011 Dan Desember 2011.
\end{abstract}

Keywords: Efesiensi, Metode DEA, Bank Umum Syariah 


\begin{abstract}
Performance is one of the indicators of efficiency in a firm including Islamic banks. Performance measurament commonly done by Islamic banks using financial ratio. However performance measurament by using financial ratio can 't show the condition of Islamic banks truthfully. Data Envelopment Analysis (DEA) method can overcome restrictiveness of performance measurament which able to handle many input and output. DEA method is a linier programming which aim to maximize input and output. This study aims to aware and analyze financial performance of Islamic commercial bank with DEA method in period 2008-2011. The sample of two Islamic commercial bank: Bank Muamalat Indonesia and Bank Syariah Mandiri. This study uses input variables consist of deposits, assets, and personnel costs as well as using a variable output which comprises the amount of financing and operating income. These results indicate that Islamic commercial bank foreign exchange continue to have 100 percent efficiency is a Bank Muamalat Indonesia over a period of observation, while Bank Syariah Mandiri has 100 percent efficiency in Maret 2008, September 2008, Desember 2008, Juni 2009, September 2009, Desember 2009, September 2010, Desember 2010, Maret 2011, Juni 2011, September 2011 dan Desember 2011.
\end{abstract}

Keywords: effeciency, DEA method, Islamic commercial bank

\title{
Pendahuluan
}

Cetak Biru Pengembangan Perbankan Syariah dari Bank Indonesia (2002), menyebutkan bahwa selama krisis ekonomi dan moneter yang terjadi tahun 1997-1998, banyak lembaga keuangan yang mengalami kesulitan keuangan termasuk dunia perbankan. Tingginya tingkat suku bunga telah mengakibatkan tingginya biaya modal bagi sektor usaha, sehingga membuat kemampuan usaha sektor produksi menurun. Hal tersebut menyebabkan kualitas aset perbankan menurun secara drastis sementara sistem perbankan diwajibkan untuk terus memberikan imbalan kepada depositor sesuai dengan tingkat suku bunga pasar. Rendahnya kemampuan daya saing sektor produksi menjadikan peran sistem perbankan sebagai intermediator dalam kegiatan investasi berkurang. Menurut Ahmad Tadjuddin dalam Maflachatun (2010) dijelaskan bahwa krisis ekonomi tersebut akibat selisih antara tingkat suku bunga simpanan yang lebih besar dari tingkat suku bunga kredit, yang menyebabkan terjadinya spread negative, 
sehingga dapat menimbulkan risiko kebangkrutan dalam operasional perbankan. Tingginya tingkat suku bunga juga menyebabkan fungsi bank sebagai lembaga intermediasi menjadi tidak optimal. Hal tersebut terjadi karena dana perbankan lebih banyak dialihkan pada instrumen moneter daripada ke sektor riil yang merupakan penggerak pertumbuhan ekonomi nasional.

Salah bank yang dapat bertahan dari krisis yang terjadi pada penghujung tahun 90-an ini adalah Bank Muamalat Indonesia yang merupakan representasi bank dengan model syariah pertama di Indonesia. Dengan model pembiayaan yang relatif berbeda dengan perbankan konvensional, telah mampu menjaga posisi NPL dalam kondisi yang aman. Hal ini mampu menopang kinerja Bank Muamalat secara keseluruhan.

Salah satu aspek penting dalam pengukuran kinerja bank adalah efisiensi yang antara lain dapat ditingkatkan melalui penurunan dalam proses produksi. Bank yang lebih efisien diharapkan akan mendapat keuntungan yang optimal, dana pinjaman yang lebih banyak, dan kualitas servis yang lebih baik pada nasabahnya. Tingkat efisiensi yang dicapai merupakan cerminan dari kualitas kinerja yang baik (Sutawijaya dan Lestari, 2009).

Teori efisiensi awalnya merupakan konsep dari mikroekonomi, yaitu teori konsumsi dan teori produksi. Teori konsumsi mencoba memaksimalkan kegunaan atau kepuasan terhadap suatu barang atau kebutuhan, sedangkan teori produksi mencoba memaksimalkan keuntungan dan meminimalkan harga dari kebutuhan produksi. Efisiensi terdiri dari dua komponen, pertama; Efisiensi teknis (technical efficiency) menunjukkan kemampuan perusahaan untuk mencapai output semaksimal mungkin dari sejumlah input. Kedua; Efisiensi alokatif (allocative efficiency) menunjukkan kemampuan perusahaan untuk menggunakan input dengan proporsi seoptimal mungkin pada tingkat harga input tertentu (Farrel dalam Ascarya, 2008). Dua komponen ini kemudian dikombinasikan untuk menghasilkan ukuran efisiensi total atau efisiensi ekonomis (economic efficiency).

Kinerja bank sering digunakan untuk menilai tingkat kesehatan bank yang bersangkutan. Tingkat kesehatan bank, termasuk tingkat efisiensi lembaga perbankan dapat dinilai dengan menggunakan berbagai indikator. Salah satu sumber utama indikator yang dijadikan dasar penilaian adalah laporan keuangan dari bank yang bersangkutan. Berdasarkan Surat Edaran Bank Indonesia No. 26/ BPPP/1993, tingkat kesehatan bank diukur dengan menggunakan analisis rasio 
keuangan yang sering dikenal dengan metode CAMEL (Capital adequacy, Assets quality, Management quality, Earnings, Liquidity).

Analisis rasio keuangan dengan metode CAMEL dapat dimanfaatkan untuk memprediksi tingkat keuntungan, memprediksi masa depan, dan untuk mengantisipasi kondisi di masa depan (Halkos dan Salamouris dalam Putri dan Lukviarman, 2008). Meski bermanfaat, penggunaan rasio keuangan yang berbasis pada laporan keuangan untuk mengukur kinerja bank ternyata memiliki beberapa kelemahan, yaitu:

1. Penggunaan rasio keuangan adalah pengaruh dari ukuran variabel keuangan yang sedang diteliti. Konteks ukuran variabel harus ada jaminan bahwa perbandingan antara penyebut dan pembilang seimbang. Industri perbankan yang memiliki rasio gabungan antara bank swasta, BUMN, BUMD, dan lembaga keuangan non-bank berisiko menyebabkan kesesatan (Shammari dan Salimi dalam Susilo, 2007).

2. Adanya kemungkinan bila menggunakan analisis rasio tunggal maka informasi yang didapat tidak akurat, namun bila menggunakan beberapa rasio justru bisa menyebabkan hasil yang berlawanan (Shammari dan Salimi dalam Susilo, 2007).

3. Membandingkan kinerja bank dengan menggunakan rasio keuangan bisa menimbulkan hasil yang berbeda tergantung tujuan pengukuran kinerja keuangan. Pihak yang memiliki tujuan yang berbeda bisa menggunakan rasio keuangan yang berbeda sesuai dengan kebutuhannya (Shammari dan Salimi dalam Susilo, 2007).

4. Data akuntansi yang digunakan tidak mampu mengindikasikan periode permaksimalan nilai ekonomis karena mengabaikan nilai pasar saat itu (Halkos dan Salamouris dalam Putri dan Lukviarman, 2008).

5. Penggunaan rasio keuangan tidak mempertimbangkan harga input dan bauran output serta pemilihan bobot rasio keuangan yang bersifat subyektif (Halkos dan Salamouris dalam Putri dan Lukviarman, 2008).

6. Tidak dapat menentukan perusahaan/anak mana yang paling efisien karena tidak ada konsensus untuk menentukan tingkat efisiensi (Kusumawardani et al., 2008). 
Metode lain yang bisa digunakan untuk mengukur efisiensi adalah dengan menggunakan metode Data Envelopment Analysis (DEA). DEA merupakan suatu pendekatan yang menggunakan model program linier untuk menghitung perbandingan rasio output dan input untuk semua unit yang dibandingkan dalam sebuah populasi (Abidin dan Endri, 2008). Metode DEA mampu mengatasi keterbatasan dari analisis rasio dan analisis regresi berganda. Metode ini dirancang khusus untuk mengukur efisiensi relatif suatu Decision Making Unit (DMU) yang menggunakan multi input dan multi output (Kusumawardani et al., 2008). Manfaat dari pengukuran efisiensi dengan DEA adalah sebagai tolak ukur untuk memperoleh efisiensi relatif yang berguna untuk mempermudah perbandingan antar unit ekonomi yang sama, mengukur berbagai variasi efisiensi antar unit ekonomi untuk mengidentifikasi faktor-faktor penyebabnya, dan menentukan implikasi kebijakan sehingga dapat meningkatkan tingkat efisiensinya (Insukindro dalam Sutawijaya dan Lestari, 2009).

\section{Rumusan Masalah}

Berdasarkan pada permasalahan di atas, penulis tertarik untuk melihat lebih dalam tingkat kinerja Bank Muamalat Indonesia sebagai bank umum syariah pertama yang eksis di Indonesia dan Bank Syariah Mandiri sebagai salah satu bank umum syariah kedua yang muncul di Indonesia.

Oleh karenanya, rumusan masalah dalam penelitian ini sebagai berikut: 1) Berapa tingkat efisiensi Bank Muamalat Indonesia dan Bank Syaraiah Mandiri pada periode 2008-2011; 2) Bagaimanakah tingkat efisiensi Bank Muamalat Indonesia dan Bank Syariah Mandiri periode 2008-2011 bila diukur dengan metode Data Envelopmment Analysis (DEA)?

\section{Perbedaan antara Bank Syariah dan Bank Konvensional}

Menurut sudut pandang Islam, bank merupakan suatu lembaga intermediasi yang mengalirkan investasi publik secara optimal (dengan kewajiban zakat dan pelarangan riba) yang bersifat produktif (dengan adanya pelarangan judi), yang disertai dengan etika dan sistem nilai Islam (Ascarya dan Yumanita, 2006). Bank syariah merupakan bank yang beroperasi dengan tidak mengandalkan pada 
bunga. Definisi bank syariah lainnya adalah lembaga keuangan/perbankan yang operasional dan produknya dikembangkan berdasarkan Al-Quran dan Al-Hadits Rasulullah SAW (Muhammad, 2005). Bank syariah adalah lembaga keuangan yang usaha pokoknya memberikan pembiayaan dan jasa-jasa lainnya dalam lalu lintas pembayaran serta peredaran uang yang pengoperasiannya disesuaikan dengan prinsip syariat (Sudarsono, 2004).

Bank Indonesia selaku otoritas moneter yang memberikan regulasi bagi perbankan, mengakui dua sistem yang bisa dipakai oleh bank-bank di Indonesia (dual banking system), yaitu bank konvensional dan bank syariah. Kedua bank tersebut mempunyai perbedaan. Perbedaan-perbedaan tersebut antara lain:

\section{Perbedaan Bank Konvensional dan Bank Syariah}

\begin{tabular}{|l|l|}
\hline \multicolumn{1}{|c|}{ Bank Konvensional } & \multicolumn{1}{c|}{ Bank Syariah } \\
\hline $\begin{array}{l}\text { 1. Melakukan investasi-investasi yang } \\
\text { halal dan haram }\end{array}$ & $\begin{array}{l}\text { 1) Melakukan investasi-investasi yang } \\
\text { halal saja. }\end{array}$ \\
$\begin{array}{l}\text { 2. Menggunakan perangkat bunga } \\
\text { 3. Bersifat profit oriented }\end{array}$ & $\begin{array}{l}\text { 2) Berdasarkan prinsip bagi hasil, jual- } \\
\text { beli dan sewa. }\end{array}$ \\
$\begin{array}{ll}\text { 4. Hubungan dengan nasabah dalam } \\
\text { bentuk hubungan debitur dan kreditur. } \\
\text { 5. Tidak mempunyai Dewan Pengawas } \\
\text { Syariah (DPS). }\end{array}$ & $\begin{array}{l}\text { 3) Bersifat profit dan falah oriented. } \\
\text { bentuk hubungan kemitraan. }\end{array}$ \\
& $\begin{array}{l}\text { 5) Penghimpunan dan penyaluran dana } \\
\text { harus sesuai dengan fatwa Dewan } \\
\text { Pengawas Syariah (DPS). }\end{array}$ \\
\hline
\end{tabular}

(Sumber: Antonio, M. Syafi'i, 2001)

\section{Konsep Efisiensi Bank}

Efisiensi merupakan salah satu parameter kinerja yang secara teoritis mendasari seluruh kinerja sebuah organisasi/perusahaan dengan mengacu pada pedoman "kemampuan menghasilkan output yang optimal dengan input-nya yang ada, adalah ukuran dari kinerja yang diharapkan" (Abidin dan Endri, 2008). Menurut Farrel dalam Ascarya, Yumanita dan Rokhimah (2008), efisiensi suatu perusahaan terdiri dari dua komponen, yaitu efisiensi teknis dan efisiensi alokatif. Efisiensi teknis mencerminkan kemampuan dari perusahaan dalam menghasilkan output 
dengan sejumlah input yang ada. Sedangkan efisiensi alokatif mencerminkan kemampuan perusahaan dalam mengoptimalkan penggunaan input, dengan struktur harga dan teknologi produksinya. Kedua efisiensi tersebut jika dikombinasikan akan menjadi efisiensi ekonomis. Suatu perusahaan dikatakan efisien secara ekonomi jika perusahaan dapat meminimalkan biaya produksi untuk menghasilkan output tertentu dengan suatu tingkat teknologi yang umumnya digunakan serta harga pasar yang berlaku.

Adapun faktor yang menyebabkan efisiensi antara lain (Sutawijaya dan Lestari, 2009): a) Input yang sama menghasilkan output yang lebih besar; b) Input yang lebih kecil menghasilkan output yang sama; c) Input yang lebih besar menghasilkan output yang lebih besar.

Menurut Berger dan Mester (dalam Abidin dan Endri 2008), efisiensi dalam industri perbankan ditinjau dari dua perspektif, yaitu perspektif mikro dan perspektif makro. Dalam efesiensi perbankan perspektif mikro, terdapat persaingan yang semakin ketat antar sebuah bank dengan bank lainnya, agar dapat bertahan dan berkembang harus efisien dalam kegiatan operasionalnya. Bank-bank yang tidak efisien, kemungkinan besar akan tersingkir dari pasar karena tidak mampu bersaing dengan kompetitornya, baik dari segi harga maupun kualitas produk dan pelayanan. Bank yang tidak efisien akan sulit dalam mempertahankan kesetiaan nasabahnya dan juga tidak diminati oleh calon nasabah dalam rangka untuk memperbesar customer base-nya. Sedangkan dalam efesiensi perbankan perspektif makro, industri perbankan yang efisien dapat mempengaruhi biaya intermediasi keuangan dan secara keseluruhan stabilitas sistem keuangan. Hal ini disebabkan peran yang sangat strategis dari industri perbankan sebagai lembaga intermediasi dan produser jasa-jasa keuangan. Dengan tingkat efisiensi yang lebih tinggi, kinerja perbankan akan semakin lebih baik dalam mengalokasikan sumber daya keuangan, dan akhirnya dapat meningkatkan kegiatan investasi dan pertumbuhan ekonomi.

Menurut Muharam dan Pusvitasari (dalam Maflachatun 2010), ada tiga jenis pendekatan pengukuran efisiensi khususnya dalam industri perbankan, yaitu:

1) Pendekatan rasio, yaitu pengukuran efisiensi dilakukan dengan cara menghitung perbandingan output dengan input yang digunakan. Pendekatan ini akan dinilai memiliki efisiensi yang tinggi, apabila dapat memproduksi jumlah output yang maksimal dengan input tertentu. Kelemahan pen- 
dekatan ini adalah apabila terdapat banyak input dan output yang akan dihitung secara bersamaan, sehingga banyak perhitungan yang menimbulkan asumsi yang tidak tegas.

2) Pendekatan regresi, yaitu pendekatan yang menggunakan sebuah model dari tingkat output tertentu sebagai fungsi dari berbagai tingkat input tertentu. Kelemahan pendekatan ini adalah tidak dapat mengatasi kondisi banyak output, karena hanya satu indikator output yang dapat ditampung dalam sebuah persamaan regresi. Dan apabila dilakukan penggabungan banyak output dalam indikator, informasi yang dihasilkan menjadi tidak rinci lagi.

3) Pendekatan frointer, memliki dua jenis yaitu parametrik dan non-parametrik. Untuk jenis parametrik terdiri dari Stochastic Frointer Approuch (SFA), Distribution Free Approuch (DFA) dan Thick Frointer Approuch (TFA), sedangkan untuk non-parametrik menggunakan Data Envelopment Analysis (DEA).

\section{Hubungan Input dan Output dalam Pengukuran Efisiensi Bank}

Pengukuran efisiensi dengan pendekatan parametrik dan non-parametrik tidak mempunyai konsensus yang baku dalam menentukan input dan output dalam model pendekatan operasional bank (Berger dan Humphrey dalam Yuniarti, 2008). Pada dasarnya ada tiga pendekatan model perilaku bank dalam menspesialisasikan input dan output, yaitu:

a) Pendekatan aset, memandang lembaga keuangan seperti bank sebagai pencipta pinjaman dan mendefinisikan output sebagai stok pinjaman dan aset investasi (Favero dan Papi dalam Kusumawardani, 2008).

b) Pendekatan produksi, menganggap bahwa model lembaga keuangan seperti bank sebagai produsen atas deposit dan pinjaman. Output dinyatakan sebagai jumlah dari rekening-rekening tersebut, dan inputnya dinyatakan oleh jumlah tenaga kerja dan pengeluaran modal pada aktiva tetap (Sherman dan Gold dalam Kusumawardani, 2008).

c) Pendekatan intermediasi, menitikberatkan lembaga keuangan perbankan sebagai perantara yang mentransfer dana dari unit ekonomi yang meng- 
alami surplus ke unit ekonomi yang mengalami defisit. Berdasarkan pendekatan ini, input utamanya digambarkan secara umum dalam bentuk biaya operasional dan biaya bunga, sedang yang dianggap sebagai output adalah pendapatan bunga, total pinjaman, total deposito, dan pendapatan selain bunga (Berger dan Humphrey dalam Kusumawardani, 2008).

\section{Data Envelopment Analysis (DEA)}

Data Envelopment Analysis (DEA) merupakan metodologi yang digunakan untuk mengevaluasi produktivitas dari suatu unit pengambilan keputusan (unit kerja) yang bertanggung jawab menggunakan sejumlah input untuk memperoleh suatu output yang ditargetkan (Purwantoro, 2005). Menurut Abidin dan Endri (2008), metode DEA adalah metode frointer non-parametric yang menggunakan model program linier (salah satu teknik penelitian operasional yang digunakan paling luas dan diketahui dengan baik, serta berupa metode matematik, yang berfungsi mengalokasikan sumber daya yang langka untuk mencapai tujuan tunggal seperti memaksimumkan keuntungan dan meminimumkan biaya) untuk menghitung perbandingan rasio output dan input untuk semua unit yang dibandingkan dalam suatu populasi. Tujuan metode DEA adalah untuk mengukur tingkat efisiensi dari Decision Making Unit (DMU) bank relatif terhadap bank yang sejenis ketika semua unit-unit ini berada pada atau di bawah kurva efisien frointer-nya.

Manfaat dari pengukuran efisiensi dengan DEA adalah sebagai tolak ukur untuk memperoleh efisiensi relatif yang berguna untuk mempermudah perbandingan antar unit ekonomi yang sama, mengukur berbagai variasi efisiensi antar unit ekonomi untuk mengidentifikasi faktor-faktor penyebabnya, dan menentukan implikasi kebijakan sehingga dapat meningkatkan tingkat efisiensinya (Insukindro dalam Sutawijaya dan Lestari, 2009). Suatu DMU dikatakan efisien jika memiliki skor efisiensi sebesar 1 atau 100\% dan dikatakan kurang efisien jika skor efisiensinya kurang dari 1 atau 100\%. Jika suatu DMU kurang efisien, maka DEA akan menunjukkan sejumlah DMU yang memiliki efisiensi dan seperangkat angka pengganda (multiplier) yang digunakan sebagai referensi atau benchmark untuk menyusun strategi perbaikan (Kusumawardani et al., 2008). 
Metode DEA memiliki keunggulan dan kelemahan (Purwantoro, 2005). Di antara keunggulan DEA, adalah: 1) Dapat menangani banyak input dan output; 2) Tidak membutuhkan asumsi hubungan fungsional antara variabel input dan output; 3) DMU dibandingkan secara langsung dengan sesamanya; 4) Input dan output dapat memilki satuan pengukuran yang berbeda. Adapun kelemahan DEA sebagai berikut: 1) Bersifat sample specific; 2) Merupakan extreme point technique, kesalahan pengukuran bisa berakibat fatal; 3) Hanya mengukur produktivitas relatif dari DMU bukan produktifitas absolut; 4) Uji hipotesis secara statistik atas hasil sulit dilakukan; 5) Menggunakan perumusan linier programming terpisah untuk tiap DMU (perhitungan secara manual sulit dilakukan apalagi untuk masalah berskala besar).

\section{Variabel-Variabel Penelitian}

Identifikasi variabel input-output yang digunakan dalam pengukuran perbandingan efisiensi kinerja merupakan langkah pertama dan terpenting karena hasil evaluasi kinerja nantinya sangat tergantung pada pilihan input-output yang dipakai (Purwantoro, 2005).

Sebagai pedoman dapat dikatakan bahwa hubungan antar variabel input dan output harus didasarkan pada sifat exclusivity dan exhaustiveness yang berarti bahwa hanya variabel input yang dapat mempengaruhi variabel output yang digunakan dalam pengukuran saja dipengaruhi. Disyaratkan agar variabel input yang digunakan mencakup seluruh sumber daya dan variabel output mencakup seluruh hasil operasi.

Dalam penelitian ini, variabel input yang diangkat berupa; Simpanan $\left(\mathrm{I}_{1}\right)$, Biaya Personalia $\left(\mathrm{I}_{2}\right)$ dan Total Asset $\left(\mathrm{I}_{3}\right)$. Sedangkan variabel output yang digunakan adalah; Pembiayaan $\left(\mathrm{O}_{1}\right)$ dan Pendapatan Operasional $\left(\mathrm{O}_{2}\right)$.

Variabel input yang digunakan dalam penelitian ini adalah simpanan $\left(\mathrm{I}_{1}\right)$, beban personalia $\left(\mathrm{I}_{2}\right)$, dan total asset $\left(\mathrm{I}_{3}\right)$. Berikut definisi operasional dari masing-masing variabel input:

\section{a. Simpanan $\left(\mathrm{I}_{1}\right)$}

Simpanan adalah sejumlah dana masyarakat baik individu maupun berbadan hukum yang berhasil dihimpun oleh bank syariah baik yang tergolong dalam 
Bank Umum Syariah (BUS) melalui produk-produk penghimpunan dana dalam satuan jutaan rupiah (Maflachatun, 2010). Variabel simpanan digunakan sebagai input karena seberapa besar fungsi intermediari bank syariah nampak pada seberapa jumlah simpanan yang dapat dihimpun dan disalurkan kembali dalam bentuk pembiayaan. Adapun simpanan yang dihimpun bank syariah dari masyarakat, antara lain:

1) Giro Syariah adalah simpanan yang penarikannya dapat dilakukan setiap saat dengan menggunakan cek, bilyet giro, sarana perintah pembayaran lainnya, atau dengan pemindahbukuan yang berdasarkan pada prinsip wadiah (Susanto, 2008).

2) Tabungan Syariah, yaitu simpanan yang penarikannya dapat dilakukan menurut syarat tertentu yang disepakati, tetapi tidak dapat ditarik dengan cek, bilyet giro, dan atau alat lainnya yang dipersamakan yang berdasarkan pada prinsip wadiah dan mudharabah (Susanto, 2008).

3) Deposito Syariah, yaitu simpanan yang penarikannya hanya dapat dilakukan pada waktu-waktu tertentu menurut perjanjian antara penyimpan dengan bank yang bersangkutan dengan prinsip mudharabah, baik mudharabah mutlaqah maupun mudharabah muqayyadah (Karim, 2006).

\section{b. Beban Personalia $\left(\mathbf{I}_{2}\right)$}

Beban personalia adalah biaya gaji, biaya pendidikan, dan tunjangan kesejahteraan karyawan bank umum syariah yang diukur dalam jutaan rupiah (Maflachatun, 2010).

\section{c. Total Asset ( $\left.\mathbf{I}_{3}\right)$}

Total asset adalah jumlah aset yang dimiliki oleh bank umum syariah yang diukur dalam jutaan rupiah.

Selain variabel-variabel input yang telah dijelaskan di atas, penelitian ini juga menggunakan variabel-variabel output berupa total pembiayaan $\left(\mathrm{O}_{1}\right)$ dan pendapatan operasional $\left(\mathrm{O}_{2}\right)$. Berikut definisi operasional masing-masing variabel output: 


\section{1) Pembiayaan $\left(\mathrm{O}_{1}\right)$}

Total pembiayaan adalah produk penyaluran dana bank umum syariah, baik individu maupun yang berbadan hukum dengan menggunakan akad-akad muamalah dalam satuan jutaan rupiah. Variabel pembiayaan mengacu pada ketentuan Peraturan Bank Indonesia (PBI) No. 6/24/PBI/2004 Pasal 36 tentang akadakad yang digunakan yang meliputi:

a) Pembiayaan dengan prinsip jual beli (tijarah);

b) Pembiayaan dengan prinsip bagi hasil (syirkah);

c) Pembiayaan dengan prinsip sewa (ijarah);

d) Pembiayaan dengan akad pelengkap (hawalah, rahn, kafalah, qardh, wakalah dan lainnya).

\section{2) Pendapatan Operasional $\left(\mathrm{O}_{2}\right)$}

Pendapatan operasional adalah pendapatan yang diperoleh dari kegiatan usaha bank umum syariah yang meliputi:

a) Pendapatan dari penyaluran dana, yaitu pendapatan dari jual beli (murabahah, salam, dan istishna), sewa (ijarah), bagi hasil (mudharabah dan musyarakah), dan lainnya.

b) Pendapatan operasional lainnya, yaitu pendapatan jasa administrasi, jasa transaksi ATM, pembiayaan khusus, jasa komisi, laba (rugi) transaksi valuta asing, free system online-payment point.

\section{Populasi dan Sampel}

Populasi pada penelitian ini adalah bank umum syariah yang terdaftar sebagai bank devisa di Bank Indonesia. Jumlah bank umum syariah yang menyandang predikat bank devisa ada empat bank, yaitu Bank Muamalat Indonesia, Bank Syariah Mandiri, Bank Mega Syariah dan Bank BNI Syariah.

Hasan (2008) mengatakan bahwa sampel adalah bagian dari sebuah populasi yang dianggap dapat mewakili populasi tersebut. Pengambilan sampel dalam penelitian ini dilakukan secara purposive sampling artinya metode pemilihan sampel dipilih berdasarkan pertimbangan (judgement sampling) yang ber- 
arti pemilihan sampel secara tidak acak yang informasinya diperoleh dengan pertimbangan tertentu. Adapun kriteria dalam pengambilan sampel ini meliputi:

1. Bank umum syariah yang terdaftar sebagai bank devisa di Bank Indonesia.

2. Bank umum devisa syariah yang telah beroperasi lebih dari 5 tahun.

3. Bank umum syariah yang merupakan bank devisa yang memiliki laporan keuangan tahunan lengkap pada periode 2008-2011.

Jumlah bank umum devisa syariah di Indonesia ada empat bank, yaitu Bank Muamalat Indonesia, Bank Syariah Mandiri, Bank Mega Syariah dan Bank BNI Syariah. Namun dari keempat bank umum devisa syariah tersebut, hanya dua bank yang memenuhi kriteria untuk dijadikan sampel. Kedua bank tersebut antara lain, Bank Muamalat Indonesia dan Bank Syariah Mandiri. Bank Mega Syariah dan BNI Syariah tidak dimasukan sebagai sampel karena meski telah terdaftar sebagai bank devisa syariah, namun Bank Mega Syariah baru menyandang predikat sebagai bank devisa pada tanggal 16 Oktober 2008, sedangkan BNI Syariah baru beroperasi sebagai bank umum syariah pada 19 Juni 2010 sehingga bank ini tidak mempunyai laporan keuangan yang lengkap pada periode 2008-2011 dan belum beroperasi selama 5 tahun sebagai bank umum devisa syariah.

\section{Data, Sumber Data dan Data Envelopment Analysis (DEA)}

Data yang digunakan dalam penelitian ini adalah data sekunder yang diperoleh atau dikumpulkan dari sumber-sumber yang telah ada (Hasan, 2008). Data sekunder ini diperoleh dari laporan keuangan triwulanan bank umum devisa syariah pada tahun 2008-2011 yang dipublikasikan melalui website masing-masing bank umum devisa syariah.

Adapun data sekunder yang dibutuhkan dalam penelitian ini, antara lain:

a). Simpanan, asset dan pembiayaan yang diperoleh dari neraca dalam laporan keuangan tahunan bank umum devisa syariah yang bersangkutan selama periode pengamatan.

b). Beban personalia dan pendapatan operasional yang diperoleh dari laporan laba/rugi dan saldo laba dalam laporan keuangan tahunan bank umum devisa syariah yang bersangkutan selama periode pengamatan. 
DEA merupakan sebuah metode optimasi program matematika yang mengukur efisiensi teknik suatu Decision Making Unit (DMU) dan membandingkan secara relatif terhadap DMU yang lain (Banker dalam Sutawijaya dan Lestari, 2009).

Tujuan dari penelitian ini adalah untuk mengetahui kinerja keuangan perbankan syariah (khususnya Bank Umum Devisa Syariah) di Indonesia selama periode 2008-2011 dengan studi pada dua bank dengan mengukur tingkat efisiensi yang menggunakan pendekatan non-parametrik yaitu Data Envelopment Analysis (DEA). Berikut langkah-langkah untuk mengukur efisiensi dengan DEA:

a). Analisis unit-unit yang akan dikendalikan, yang meliputi penentuan sumber daya (input) yang dimanfaaatkan serta output yang dihasilkan.

B). Menghitung model matematis DEA.

Efisiensi relatif DMU dalam DEA didefinisikan sebagai rasio dari total output tertimbang dengan total input tertimbang. Setiap DMU diasumsikan bebas menentukan bobot untuk variabel-variabel input maupun output yang ada, asalkan mampu memenuhi dua kondisi yang disyaratkan yaitu (Nugroho dalam Huri dan Susilowati, 2004):

1) Bobot tidak boleh negatif.

2) Bobot harus bersifat universal atau menghasilkan indikator efisiensi yang normal dan atau tidak boleh lebih dari nilai 1 (rasio total output tertimbang/total input tertimbang $\leq 1$ )

Asumsi yang digunakan oleh DEA yaitu setiap DMU akan memiliki bobot yang memaksimalkan rasio efisiensi. Setiap DMU akan menggunakan kombinasi input yang berbeda untuk menghasilkan output yang berbeda pula. Oleh karena itu setiap DMU akan memiliki seperangkat bobot yang mencerminkan keragaman tersebut. Pada umumnya DMU akan menetapkan bobot yang lebih tinggi untuk input yang sedikit digunakan dan pada output yang banyak dihasilkan. Bobot tersebut sebagai penentu untuk memaksimalkan efisiensi suatu DMU (Nugroho dalam Huri dan Susilowati, 2004). 


\section{Formulasi DEA:}

Misalkan terdapat $\mathrm{n}$ buah DMU yang akan dibandingkan efisiensinya, dimana setiap DMU menggunakan sejumlah $\mathrm{m}$ jenis input untuk menghasilkan $\mathrm{s}$ jenis output.

Misalkan $\mathrm{X}_{\mathrm{ij}}>0$ merupakan input i yang digunakan oleh DMU $\mathrm{j}$, dan misalkan $\mathrm{Y}_{\mathrm{rj}}>$ merupakan jumlah output yang dihasilkan oleh DMU $\mathrm{j}$.

Misalnya $X_{i k}>0$ merupakan input i yang digunakan oleh DMU k, dan misalkan $\mathrm{Y}_{\mathrm{rk}}>0$ merupakan jumlah output $\mathrm{r}$ yang dihasilkan oleh DMU $\mathrm{k}$.

Variabel keputusan dari kasus tersebut bobot yang harus diberikan pada setiap input dan output oleh DMU k.

Misal:

$\mathrm{V}_{\mathrm{ik}}=$ bobot yang diberikan pada input $\mathrm{i}$ oleh DMU $\mathrm{k}$.

$\mathrm{U}_{\mathrm{rk}}=$ bobot yang diberikan pada output $\mathrm{r}$ oleh DMU k.

Sehingga $V_{i k}$ dan $U_{r k}$ merupakan variabel keputusan yaitu variabel yang dinilainya akan ditentukan melalui interaksi program linear. Selanjutnya diformulasikan sejumlah n program fraksional, satu formulasi program linier untuk setiap DMU di dalam sampel. Fungsi tujuan dari setiap program linear fraksional tersebut adalah rasio dari output tertimbang dari DMU k dengan input tertimbang totalnya. Formulasi tujuan tersebut adalah sebagai berikut:

$$
\text { Maksimumkan } \mathrm{Z}_{\mathrm{k}}=\frac{\sum_{\mathrm{r}=1}^{\mathrm{s}} \mathrm{u}_{\mathrm{rk}} \cdot \mathrm{Y}_{\mathrm{rk}}}{\sum_{\mathrm{i}=1}^{\mathrm{m}} \mathrm{v}_{\mathrm{ik}} \cdot \mathrm{X}_{\mathrm{ik}}}
$$

Keterangan:

$$
\begin{aligned}
\mathrm{Z}_{\mathrm{k}} & =\text { efisiensi relatif } \\
\mathrm{U}_{\mathrm{rk}} & =\text { bobot untuk output DMU } \mathrm{k} \\
\mathrm{V}_{\mathrm{ik}} & =\text { bobot untuk input DMU } \mathrm{k} \\
\mathrm{Y}_{\mathrm{rk}} & =\text { jumlah output } \mathrm{r} \text { yang dihasilkan DMU k } \\
\mathrm{X}_{\mathrm{ik}} & =\text { jumlah input i yang dihasilkan DMU k } \\
\mathrm{s} & =\text { jumlah jenis output }
\end{aligned}
$$




$$
\mathrm{m} \quad \text { = jumlah jenis input }
$$

Kriteria universalitas mensyaratkan DMU k untuk memilih bobot dengan batasan/ kendala bahwa tidak ada DMU lain yang akan memiliki efisiensi lebih besar dari 1 atau 100\% jika DMU lain tersebut menggunakan bobot yang dipilih oleh DMU k. Sehingga formulasi selanjutnya adalah:

$$
\mathrm{Z}_{\mathrm{k}}=\frac{\sum_{\mathrm{r}=1}^{\mathrm{s}} \mathrm{u}_{\mathrm{rk}} \cdot \mathrm{Y}_{\mathrm{rk}}}{\sum_{\mathrm{i}=1}^{\mathrm{m}} \mathrm{v}_{\mathrm{ik}} \cdot \mathrm{X}_{\mathrm{ik}}} \leqslant 1 ; \mathrm{j}=1, \ldots \ldots, \mathrm{n}
$$

Keterangan:

$\mathrm{Y}_{\mathrm{rj}} \quad=$ jumlah output $\mathrm{r}$ yang dihasilkan DMU $\mathrm{j}$

$\mathrm{X}_{\mathrm{ij}} \quad=$ jumlah input $\mathrm{i}$ yang dihasilkan DMU $\mathrm{j}$

Bobot yang dipilih untuk tidak bernilai negatif:

$\mathrm{u}_{\mathrm{rk}} \geq 0 ; \mathrm{r}=1, \ldots \ldots, \mathrm{s}$

$\mathrm{v}_{\mathrm{ik}} \geq 0 ; \mathrm{i}=1, \ldots \ldots, \mathrm{m}$

Program linear fraksional kemudian ditransformasikan ke dalam program linear biasa dan metode simpleks dapat digunakan untuk menyelesaikannya. Transformasi program linear yang disebut dengan DEA adalah sebagai berikut:

$$
\text { DEA maksimum : } \mathrm{Z}_{\mathrm{k}}=\sum_{\mathrm{r}=1}^{\mathrm{s}} \mathrm{u}_{\mathrm{rk}} \cdot \mathrm{Y}_{\mathrm{rk}}
$$

Dengan batasan:

$$
\sum_{r=1}^{s} u_{r} \cdot Y_{r j}-\sum_{i=1}^{m} v_{i} . X_{i j} \leqslant 0 ; j=1, \ldots ., n
$$




$$
\begin{aligned}
& \sum_{\mathrm{i}=1}^{\mathrm{m}} \mathrm{v}_{\mathrm{ik}} \cdot \mathrm{X}_{\mathrm{ik}}=1 \\
& \mathrm{u}_{\mathrm{rk}} \geqslant 0 ; \mathrm{r}=1, \ldots, \mathrm{s} \\
& \mathrm{v}_{\mathrm{ik}} \geqslant 0 ; \mathrm{i}=1, \ldots ., \mathrm{m}
\end{aligned}
$$

Dalam penelitian ini, pengolahan data input dan output untuk menghitung efisiensi dari satu sisi (primal) yaitu maksimalisasi output. Dan untuk menyelesaikan perhitungannya, peneliti menggunakan software WDEA222.

\section{Hasil Analisis Deskriptif Variabel Input dan Output}

Statistik deskriptif bertujuan untuk mengetahui gambaran atau deskripsi secara statistik suatu data yang dilihat dari nilai minimum, nilai maksimum, nilai rata-rata dan standar deviasi masing-masing variabel. Berikut uji statistik yang dilakukan terhadap variabel input dan output kedua Bank Umum Devisa Syariah selama periode 2008-2011:

$$
\begin{gathered}
\text { Statistik Deskriptif Variabel Input-Output } \\
\text { Periode 2008-2011 } \\
\text { (dalam jutaan rupiah) }
\end{gathered}
$$

\section{Descriptive Statistics}

\begin{tabular}{|l|c|l|l|l|l|}
\hline & N & Minimum & Maximum & Mean & Std. Deviation \\
\hline Simpanan & 32 & 9134198 & 42133653 & 18752054 & 8670994.974 \\
Asset & 32 & 11062620 & 48671950 & 21811869 & 9623741.996 \\
Beban_Personalia & 32 & 35195 & 964882 & 241588 & 203338.093 \\
Pembiayaan & 32 & 8742831 & 36520957 & 15699650 & 7119247.120 \\
Pendapatan_Operasional & 32 & 339703 & 5056218 & 1565840 & 1041349.158 \\
Valid N (listwise) & 32 & & & & \\
\hline
\end{tabular}

Sumber: Laporan Keuangan triwulan BMI dan BSM dari situs masing-masing yang diolah dengan SPSS 16.0 for windows 
Tabel di atas menjelaskan beberapa hal, sebagai berikut:

a. $\quad \mathrm{N}$ atau jumlah data yang valid adalah sebanyak 32 , karena data yang hilang adalah 0 maka semua data layak untuk diproses.

b. Mean atau nilai rata-rata simpanan dari kedua bank berdasarkan laporan keuangan triwulanan masing-masing bank selama periode 2008-2011 adalah Rp. 18.752.054 dengan standar deviasi Rp. 8.670.994,974 yang menunjukkan seberapa besar nilai penyimpangannya. Nilai minimal simpanan adalah Rp. 9.134.198 dan nilai maksimalnya sebesar Rp. 42.133.653.

c. Mean atau nilai rata-rata asset dari kedua bank berdasarkan laporan keuangan triwulanan masing-masing bank selama periode 2008-2011 adalah Rp. 21.811.869 dengan standar deviasi Rp. 9.623.741,996 yang menunjukkan seberapa besar nilai penyimpangannya. Nilai minimal simpanan adalah Rp. 11.062.620 dan nilai maksimalnya adalah Rp. 48.671.950.

d. Mean atau nilai rata-rata beban personalia dari kedua bank berdasarkan laporan keuangan triwulanan masing-masing bank selama periode 20082011 adalah Rp. 241.588 dengan standar deviasi Rp. 203.338,093 yang menunjukkan seberapa besar nilai penyimpangannya. Nilai minimal simpanan adalah Rp. 35.195 dan nilai maksimalnya adalah Rp. 964.882.

e. Mean atau nilai rata-rata pembiayaan dari kedua bank berdasarkan laporan keuangan triwulanan masing-masing bank selama periode 2008-2011 adalah Rp. 15.699.650 dengan standar deviasi Rp. 7.119.247,120 yang menunjukkan seberapa besar nilai penyimpangannya. Nilai minimal simpanan adalah Rp. 8.742.831 dan nilai maksimalnya adalah Rp. 36.520.957.

f. Mean atau nilai rata-rata pendapatan operasional dari kedua bank berdasarkan laporan keuangan triwulanan masing-masing bank selama periode 2008-2011 adalah Rp. 1.565.840 dengan standar deviasi Rp. 1.041.349,158 yang menunjukkan seberapa besar nilai penyimpangannya. Nilai minimal simpanan adalah Rp. 339.703 dan nilai maksimalnya adalah Rp. 5.056.218.

\section{Hasil Analisis Efisiensi dengan Data Envelopment Analysis}

Berdasarkan hasil perhitungan metode DEA yang diolah dengan menggunakan software WDEA222, dapat dilihat tingkat efisiensi dua bank umum devisa syariah di Indonesia ini sebagai berikut: 
Tingkat Efisiensi Bank Umum Devisa Syariah

Periode 2008-2011

(dalam persen)

\begin{tabular}{|l|l|l|l|l|}
\hline \multirow{2}{*}{\multicolumn{1}{|c|}{ DMU }} & \multicolumn{4}{c|}{ Tahun } \\
\cline { 2 - 5 } & \multicolumn{1}{|c|}{2008} & \multicolumn{1}{c|}{2009} & \multicolumn{1}{c|}{2010} & 2011 \\
\hline BMI_Maret & 100,00 & 100,00 & 100,00 & 100,00 \\
\hline BMI_Juni & 100,00 & 100,00 & 100,00 & 100,00 \\
\hline BMI_September & 100,00 & 100,00 & 100,00 & 100,00 \\
\hline BMI_Desember & 100,00 & 100,00 & 100,00 & 100,00 \\
\hline BSM_Maret & 100,00 & 95,05 & 99,47 & 100,00 \\
\hline BSM_Juni & 98,30 & 100,00 & 91,12 & 100,00 \\
\hline BSM_September & 100,00 & 100,00 & 100,00 & 100,00 \\
\hline BSM_Desember & 100,00 & 100,00 & 100,00 & 100,00 \\
\hline
\end{tabular}

Hasil olah data dengan WDEA222

Hasil perhitungan tersebut menggambarkan pencapaian nilai tingkat efisiensi masing-masing bank sangat beragam. Selama periode penelitian yaitu Maret 2008 sampai dengan Desember 2011 Bank Muamalat Indonesia selalu mengalami efisiensi 100\%. Sedangkan Bank Syariah Mandiri pada periode Juni 2008 mengalami efisiensi sebesar 98,30\%, periode Maret 2009 sebesar 95,05\%, periode Maret 2010 sebesar 99,47\%, periode Juni 2010 sebesar 91,12\%, dan selebihnya pada periode Maret 2008, September 2008, Desember 2008, Juni 2009, September 2009, Desember 2009, September 2010, Desember 2010, Maret 2011, Juni 2011, September 2011 dan Desember 201,1, Bank Syariah Mandiri mengalami efisiensi sebesar $100 \%$.

Metode Data Envelopment Analysis (DEA) dapat memberikan arah dan stategi bagi para manajer untuk meningkatkan efisiensi suatu bank. Bank-bank yang inefisien, dapat dikatakan bahwa bank tersebut belum dapat memaksimalkan nilai input dan output yang dimilikinya. Hal ini berarti nilai input dan output yang dicapai oleh bank yang mengalami inefisien belum dapat meraih target yang sebenarnya (Muharam H. dan Pusvitasari dalam Maflachatun, 2010). Berikut target yang harus dicapai oleh bank-bank yang mengalami inefisiensi agar dapat mencapai tingkat efisien: 
Target Input dan Output Bank Syariah Mandiri

Juni 2008

Targets for Unit BSM0608 efficiency 98.30\% radial

VARIABLE ACTUAL TARGET TO GAIN ACHIEVED

$\begin{array}{lllll}\text {-IN1 } & 14189879.0 & 13320541.4 & 6.1 \% & 93.9 \%\end{array}$

$\begin{array}{lllll}- \text {-IN2 } & 16285555.0 & 16009012.9 & 1.7 \% & 98.3 \%\end{array}$

$\begin{array}{lllll}- \text {-IN3 } & 141758.0 & 129808.8 & 8.4 \% & 91.6 \%\end{array}$

$\begin{array}{lllll}+ \text { OUT1 } & 12725201.0 & 13569187.8 & 6.6 \% & 93.8 \%\end{array}$

\begin{tabular}{lllll}
+ OUT2 & 981597.0 & 981597.0 & $0.0 \%$ & $100.0 \%$ \\
\hline
\end{tabular}

Sumber: Laporan Keuangan Triwulan II Bank Syariah Mandiri tahun 2008, diolah dengan WDEA222

Tingkat efisiensi Bank Syariah Mandiri (BSM) Juni 2008 adalah 98,30 persen. Untuk mencapai efisiensi, BSM dapat melakukan cara menetapkan target

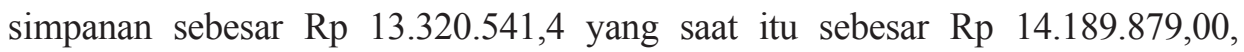
menetapkan target asset sebesar Rp 16.009.012,9 yang saat itu sebesar Rp 16.285.555,00, menetapkan target beban personalia sebesar Rp 129.808,8 yang awalnya Rp 141.758,00, menetapkan target pembiayaan sebesar Rp 13.569.187,8 yang awalnya $\mathrm{Rp} 12.725 .201$, serta menetapkan target pendapatan operasional sebesar Rp 981.597 yang telah sesuai dengan kondisi saat itu.

Target Input dan Output Bank Syariah Mandiri

Maret 2009

Targets for Unit BSM0309 efficiency 95.05\% radial

VARIABLE ACTUAL TARGET TO GAIN ACHIEVED

$\begin{array}{lllll}\text {-IN1 } & 15357254.0 & 13600843.4 & 11.4 \% & 88.6 \%\end{array}$

$\begin{array}{lllll}- \text {-IN2 } & 17704474.0 & 16828505.9 & 4.9 \% & 95.1 \%\end{array}$

$\begin{array}{lllll}- \text { IN3 } & 77343.0 & 52238.0 & 32.5 \% & 67.5 \%\end{array}$

$\begin{array}{lllll}+ \text { OUT1 } & 13388886.0 & 13388886.0 & 0.0 \% & 100.0 \%\end{array}$

\begin{tabular}{lrrrr}
+ OUT2 & 558820.0 & 559533.8 & $0.1 \%$ & $99.9 \%$ \\
\hline
\end{tabular}

Sumber: Laporan Keuangan Triwulan I Bank Syariah Mandiri tahun 2009, diolah dengan WDEA222 
Tingkat efisiensi Bank Syariah Mandiri (BSM) Maret 2009 adalah 95,05 persen. Untuk mencapai efisiensi, BSM dapat melakukan cara menetapkan target simpanan sebesar Rp 13.600.843,4 yang saat itu sebesar Rp 15.357.254, menetapkan target asset sebesar Rp 16.828.505,9 yang saat itu sebesar Rp 17.704.474, menetapkan target beban personalia sebesar Rp 52.238 yang awalnya $\mathrm{Rp} 77.343$, menetapkan target pembiayaan sebesar Rp 13.388.886 yang telah sesuai dengan kondisi saat itu serta menetapkan target pendapatan operasional sebesar $\mathrm{Rp}$ $559.533,8$ yang pada saat itu sebesar Rp 558.820.

\section{Target Input dan Output Bank Syariah Mandiri}

Maret 2010

Targets for Unit BSM0310 efficiency $99.47 \%$ radial

\begin{tabular}{lllll} 
VARIABLE & ACTUAL & TARGET & TO GAIN & ACHIEVED \\
\hline -IN1 & 20885271.0 & 19199823.7 & $8.1 \%$ & $91.9 \%$ \\
-IN2 & 23812128.0 & 23686342.0 & $0.5 \%$ & $99.5 \%$ \\
-IN3 & 98460.0 & 94605.8 & $3.9 \%$ & $96.1 \%$ \\
+OUT1 & 17566137.0 & 19031867.2 & $8.3 \%$ & $92.3 \%$ \\
+OUT2 & 719657.0 & 719657.0 & $0.0 \%$ & $100.0 \%$ \\
\hline
\end{tabular}

Sumber: Laporan Keuangan Triwulan I Bank Syariah Mandiri tahun 2010, diolah dengan WDEA222

Tingkat efisiensi Bank Syariah Mandiri (BSM) Maret 2010 adalah 99,47 persen. Untuk mencapai efisiensi, BSM dapat melakukan cara menetapkan target simpanan sebesar Rp 19.199.823,7 yang saat itu sebesar Rp 20.885.271, menetapkan target asset sebesar Rp 23.686.342 yang saat itu sebesar Rp 23.812.128, menetapkan target beban personalia sebesar $\mathrm{Rp} 94.605,8$ yang awalnya $\mathrm{Rp}$ 98.460, menetapkan target pembiayaan sebesar Rp 19.031.867,2 yang awalnya Rp 17.566.137 telah serta menetapkan target pendapatan operasional sebesar Rp 719.657 yang sesuai dengan kondisi pada saat itu. 
Target Input dan Output Bank Syariah Mandiri

Juni 2010

Targets for Unit BSM0610 efficiency $91.12 \%$ radial

\begin{tabular}{lllll} 
VARIABLE & ACTUAL & TARGET & TO GAIN & ACHIEVED \\
\hline -IN1 & 23091575.0 & 19120572.3 & $17.2 \%$ & $82.8 \%$ \\
-IN2 & 26384992.0 & 23850540.4 & $9.6 \%$ & $90.4 \%$ \\
-IN3 & 211495.0 & 192706.5 & $8.9 \%$ & $91.1 \%$ \\
+OUT1 & 19762913.0 & 19762913.0 & $0.0 \%$ & $100.0 \%$ \\
+OUT2 & 1511713.0 & 1352299.4 & $10.55 \%$ & $89.45 \%$
\end{tabular}

Sumber: Laporan Keuangan Triwulan IV BSM tahun 2006, diolah dengan DEA Excel Solver

Tingkat efisiensi Bank Syariah Mandiri (BSM) Juni 2010 adalah 91.12 persen. Untuk mencapai efisiensi, BSM dapat melakukan cara menetapkan target simpanan sebesar Rp 19.120.572,3 yang saat itu sebesar Rp 23.091.575, menetapkan target asset sebesar Rp 23.850.540,4 yang saat itu sebesar Rp 26.384.992, menetapkan target beban personalia sebesar Rp 192.706,5 yang awalnya Rp 211.495, menetapkan target pembiayaan sebesar Rp 19.762.913 yang telah sesuai dengan kondisi saat itu serta menetapkan target pendapatan operasional sebesar Rp 1.352.299,4 yang awalnya Rp 1.511.713.

Perhitungan DEA tidak hanya mengukur nilai efisiensi dari masing-masing bank umum devisa syariah yang ada dalam sampel, tetapi juga memberikan benchmark/referensi atau acuan bagi bank yang berada dalam kondisi inefisien agar dapat meningkatkan tingkat efisiennya (Muharam H. Dan Pusvitasari, 2007 dalam Maflachatun, 2010, 102). Berikut tabel yang menunjukkkan acuan atau referensi bagi bank yang inefisien untuk menjadi efisien serta bobotnya. 
Benchmark Input Oriented Model

dengan Bank Umum Devisa Syariah Efisien

Tahun 2008-2011

\begin{tabular}{|c|l|c|c|c|}
\hline \multirow{2}{*}{ No. } & \multirow{2}{*}{ Bank } & \multirow{2}{*}{$\begin{array}{c}\text { Efisiensi } \\
\text { (persen) }\end{array}$} & \multicolumn{2}{|c|}{ Benchmark } \\
\cline { 4 - 5 } & & Bobot & Bank \\
\hline 1. & BSM0608 & 98,30 & 1,426 & BMI0608 \\
\hline 2. & BSM0309 & 95,05 & 1,256 & BMI0309 \\
\hline 3. & BSM0310 & 99,47 & 1,597 & BMI0310 \\
\hline 4. & BSM0610 & 91,12 & 1,548 & BMI0610 \\
\hline
\end{tabular}

Hasil olah data dengan WDEA222

\section{Tingkat Efisiensi BMI dan BSM Melalui Analisis DEA.}

Berdasarkan data seperti tersebut di atas, dapat dilihat bahwa selama periode penelitian, Bank Muamalat Indonesia memiliki tingkat efisiensi 100\%. Sedangkan Bank Syariah Mandiri mengalami efisiensi 100\% pada Maret 2008, September 2008, Desember 2008, Juni 2009, September 2009, Desember 2009, September 2010, Desember 2010, Maret 2011, Juni 2011, September 2011 dan Desember 2011. Sedangkan pada periode Juni 2008 (98,30\%), Maret 2009 (95,05\%), Maret 2010 (99,47\%) dan Juni 2010 (91,12\%), Bank Syariah Mandiri mengalami efisiensi yang kurang dari $100 \%$.

Dalam penelitian ini, pengujian DEA dilakukan berdasarkan input oriented yang berarti bahwa evaluasi yang dilakukan menggunakan dasar utama yang harus dibenahi adalah variabel input terlebih dahulu dan mengurangi variabel output. Hasil dari penelitian ini adalah sebagai berikut:

a. Pencapaian efisiensi Bank Muamalat Indonesia selama periode 20082011 mengalami tingkat efisiensi yang baik. Hal ini ditunjukkan selam tahun 2008 sampai 2011, nilai efisiensi Bank Muamalat Indonesia selalu mencapai angka konstan yaitu 1. Bahkan Bank Muamalat Indonesia selalu menjadi referensi atau acuan bagi bank yang belum efisien.

b. Pada periode Juni 2008 (98,30\%), Maret 2009 (95,05\%), Maret 2010 (99,47\%) dan Juni 2010 (91,12\%), Bank Syariah Mandiri mengalami efisiensi yang kurang dari $100 \%$. Selebihnya BSM mengalami efisiensi $100 \%$. 


\section{Penutup}

Sebagai lembaga intermediary keuangan, sebuah bank syariah dituntut untuk bisa mengalokasikan dana simpanan masyarakat ke sektor pembiayaan secara efisien. Salah satu metode yang bisa digunakan untuk melihat seberapa jauh tingkat efisiensi sebuah bank syariah adalah metode (DEA). Dari penelitian yang telah dilakukan dapat diketahui bahwa Bank Muamalat Indonesia selama periode 2008 sampai dengan 2011 telah mencapai tingkat efisiensi sebesar $100 \%$. Hal yang sama juga dicapai oleh Bank Syariah Mandiri meskipun ada pengecualian untuk bulan Juni 2008, Maret 2009, Maret 2010 serta Juni 2010. Terlepas dari hasil tersebut, bank-bank syariah harus bisa mencapai tingkat efisiensi maksimal agar bisa bersaing dengan bank lain.

\section{DAFTAR PUSTAKA}

Abidin, Zaenal dan Endri. "Analisis Efisiensi Bank Pembangunan Daerah Menggunakan Pendekatan Data Envelopment Analysis (DEA)". Ventura. Vol. 11. No.3. 2008

Antonio, M. Syafi'i. Bank Syariah dari Teori ke Praktek. 2001. Gema Insani Press. Jakarta

Ascarya, dan Yumanita. Diana. "Analisis Efisiensi Perbankan Syariah di Indonesia dengan Data Envelopment Analysis". TAZKIA Islamic Finance dan Business Review. Vol. 1. No. 1.2006

Ascarya, Yumanita dan Rokhimah, Guruh S. "Analisis Efisiensi Perbankan Konvensional dan Perbankan Syariah di Indonesia dengan Data Envelopment Analysis". Paper dalam Buku Current Issues Lembaga Keuangan Syariah. 2008. Kencana Prenada Media Group. Jakarta

Hasan, Iqbal. Pokok-Pokok Materi Statistik 1 (Statistik Deskriptif) Edisi Kedua. 2008. Bumi Aksara. Jakarta

Huri, M. D. Dan Susilowati, Indah. "Pengukuran Efisiensi Relatif Emiten Perbankan dengan Metode Data Envelopment Analysis Studi Kasus Bank-Bank yang Terdaftar di Bursa Efek Jakarta Tahun 2002”. Dinamika Pembangunan. Vol. 1. No. 2. 2004 
Karim, Adiwarman. Bank Islam Analisis Fiqih dan Keuangan. 2006. Raja Grafindo Persada. Jakarta

Kusumawardani, et al. "Tingkat Kesehatan dan Efisiensi Bank Perkreditan Rakyat Jawa Timur". Majalah Ekonomi. Tahun XVIII. No. 2. 2008

Maflachatun. Analisis Perbankan Syariah di Indonesia dengan Metode Data Envelopment Analysis (Studi pada 11Bank syariah Tahun 2005-2008). Skripsi Fakultas Ekonomi Universitas Diponegoro. 2010. Semarang

Muhammad, Manajemen Bank Syariah. Edisi Revisi. 2005. UPP AMP YKPN. Yogyakarta

Purwantoro, Nugroho. "DEA sebagai Metode Alternatif untuk Menilai Produktivitas Lembaga Pembiayaan Mikro". Manajemen Usahawan Indonesia. No. 1. Tahun XXXIV. 2005

Putri, V. R. dan Lukviarman. "Pengukuran Kinerja Bank Komersial dengan Pendekatan Efisiensi: Studi terhadap Perbankan Go Public di Indonesia". Jaai, Vol. 12, No. 1, 2008

Sudarsono, Heri. Bank dan Lembaga Keuangan Syariah Deskripsi dan Ilustrasi. Edisi Kedua. 2004. Ekonisia. Yogyakarta

Susanto, Burhanuddin. Hukum Perbankan Syariah di Indonesia. 2008. UII Press. Yogyakarta

Susilo, Ihwan. "Analisis Efisiensi Lembaga Keuangan Mikro". Jurnal Ekonomi Pembangunan. Vol. 8. No. 2. 2007

Sutawijaya, Adrian dan Lestari, Etty P. "Efisiensi Teknik Perbankan Indonesia Pascakrisis Ekonomi: Sebuah Studi Empiris Penerapan Metode DEA". Jurnal Ekonomi Pembangunan. Vol.10. No.1. 2009

Yuniarti, Sari. "Kinerja Efisiensi Bank Berstratifikasi Sesuai Dengan Visi Arsitektur Perbank Indonesia”. Jurnal Keuangan dan Perbankan. Vol. 13. No. 3. 2008 